\title{
A magyarországi idős korosztály információs írástudása és motivációi
}

A szerző statisztikai adatok segítségével vizsgálja a magyar idősek életminőség-javító eszközökkel kapcsolatos képességeit és attitűdjeit. Bemutatja, hogy az új technológiákkal kapcsolatban a vizsgált korcsoport legvilágosabban kirajzolódó véleménye egyértelműen tartózkodó vagy elzárkózó, és az érdeklődők túlnyomó többsége is bizonytalan. Az idősebb korosztálynak azok a tagjai, akik használják az internetet, többnyire sikeresen megtanulták a kezelését, és önállóan képesek élni előnyeivel. A hozzáféréssel rendelkezők között a társadalmi közvetítők segítsége 50\%-kal megnövelheti a tényleges felhasználók számát. Az adatok elemzése egyértelműen azt mutatja, hogy az időseknek az információs társadalomba való bevonása terén jelentős feladatok várnak a képzésre és az ismeretterjesztésre.

Kulcsszavak: információs írástudás, motiváció, idősek, Magyarország

\section{Szerzői információ:}

\section{Rab Árpád}

antropológus és etnográfus, jelenleg szociológiai doktori tanulmányokat folytat. Több mint egy évtizede élethivatása az információs társadalom kutatása. Kiemelt témái: az információs társadalom életminôség-javító hatásai, a digitális kultúra természetrajza, a komoly virtuális világok és játékok, valamint az e-egészségügy.

Így hivatkozzon erre a cikkre:

Rab Árpád. „A magyarországi idős korosztály információs írástudása és motivációi”.

Információs Társadalom IX, 4. szám (2009): 49-54.

https://dx.doi.org/10.22503/inftars.IX.2009.4.3

A folyóiratban közölt müvek

a Creative Commons Nevezd meg! - Ne add el! - Így add tovább! 4.0

Nemzetközi Licenc feltételeinek megfelelóen használhatók. 
Rab Árpád

\section{A magyarországi idós korosztály információs írástudása és motivációi}

Bevezetés

Mind a nemzetközi, mind a hazai szakirodalom egyre bátrabban és nyomatékosabban fogalmazza meg, hogy a nyugati társadalmak információs társadalmában a további fejlódés kulcsterülete az idôsek bevonása - as internet jövoóje a idósek bekapcsolódásától függ. ${ }^{1}$ Az Európai Unió irányelveiben szintén mind gyakrabban és hangsúlyosabban jelenik meg az idősek életminőségének javítására irányuló törekvés, az elfogadható, önálló és teljes jól-lét érzetének biztosítása. ${ }^{2}$

Az idôseknek az információs társadalomba való bevonására számos elképzelés született. Egyesek a képzés és az ismeretterjesztés fontosságát hangsúlyozzák, mások inkább a hardverek, az idősbarát esækö̋ök és az infrastruktúra vagy a szoftverek fejlesztésében látják a megoldás kulcsát. Sorra jelennek meg az időseknek szóló weboldalak, közösségi oldalak ${ }^{3}$ és különféle új alkalmazások, de az idôsek célcsoportjára fókuszál a telefon- és internet-szolgáltatók képzési és eszköz-kínálata is. ${ }^{5}$

Az idôsek várható nyeresége nyilvánvalónak túnik: a kirekesztôdés és elmagányosodás megszúnhet vagy jelentốsen csökkenhet, elônyös lehetôségek nyílnak meg a szellemi és fizikai rehabilitáció terén, számos kényelmi szolgáltatás válik elérhetôvé, csökken az információs kiszolgáltatottság, az elektronikus egészségügyi ellátás mindenütt jelenlévô, életminôségjavító szolgáltatásairól nem is beszélve.

1 Az Egyesült Államokban 2005 óta a 70-75 évesek korcsoportjában terjedt el a legnagyobb mértékben az internet: a penetráció három év alatt 26 százalékról 45\%-ra nőtt (Pew Internet Research, http://www.pewinternet. org/pdfs/PIP_Adult_social_networking_data_memo_FINAL.pdf). A nagymértékü növekedés legföbb oka nyilvánvalóan a kezdeti lemaradás aránya. A közeljövőben Magyarországon is hatalmas ugrás várható, egész egyszerüen a jelenlegi rendkívül alacsony penetráció miatt. A magyar nyugdíjasoknak mindössze 4 százaléka, azaz körülbelül 75 ezer fő tekinthető rendszeres internetezőnek (e-Befogadás éves jelentés, 2008: http://www.ittk.hu/ web/kiadvanyok.html).

2 Az Európai Unió i2010 programjának egyik fő célkitüzése az önálló élet biztosítása az öregedő társadalomban, lásd eInclusion: http://cordis.europa.eu/ist/einclusion/ és Ambient Assisted Living: www.aal169.org. E programok költségigénye egy 2007-es ajánlás 150 milliós bővítése eredményeként meghaladja a 600 millió eurót. Az EU ilyen irányú terveinek részletes áttekintését nyújtja a Health and long-term care in the European Union című kiadvány (2007 december, http://ec.europa.eu/public_opinion/archives/ebs/ebs_283_en.pdf).

3 Például a brit Saga Zone http://www.sagazone.co.uk/

4 A hazai piacon a Telekom és a UPC is kínál időseknek szóló képzést ingyen vagy jelképes összegért. Az időseknek szóló képzési programok terén látványos sikereket értek el civil szervezetek, például a „Kattints rá, Nagyi” és a „Szépkorú Netszoba” kezdeményezésekkel. Az IKT használatának oktatásáról az idősek körében remek összefoglalót és gyakorlati útmutatót ad Mimi Larsson: Az idősebbek bekapcsolódása az információs és kommunikációs technológiák alkalmazásába - a gyakorlatban (Információs Társadalom 2006/1. 91-106. old.).

5 Például a Doro HandleEasy 326gsm mobiltelefon-készülék vagy a Microsoft speciálisan időseknek készült számítógépe (SeniorPC). 
Az alábbiakban a már bemutatott kérdôíves felmérés során az információs írástudással kapcsolatban feltárt adatokat elemezzük, és a motivációk és attitûdök megismerése mellett igyekszünk ajánlásokat is megfogalmazni.

\section{Tudásszakadék ok}

Ma már közismert ténynek számít az, hogy a (digitális) eszközök felhasználói között is legalább olyan mély tudásszakadékok húzódnak, mint a használók és a nem használók között. A különféle hozzáértési szintek, a készségek és az értékteremtô vagy csak reproduktív használati módok között a használók körén belül fennálló különbségek megragadása nagyon nehéz, de a magyar információs társadalom versenyképességének megítélése szempontjából kulcsfontosságú probléma.

A válaszadók egyharmadának $(33,3 \%)$ van otthon számítógépe, és a számítógéppel rendelkezók közel 90\%-ának (88,85\%) internet-hozzáférése is van. Ez az adat egyértelmúen azt bizonyítja, hogy a számitógép és az internet egyre inkább együtt jár a hástartásokban. Vizsgálatunk útján a magyarországi idősek Televízió-, számítógép-, mobiltelefonés internet-használati szokásait és képességeit kívántuk megismerni.

Az 50-75 évesek 69,5\%-a állítja magáról, hogy képes egyedül is beállítani a $T V$ csatornákat, vagyis a TV mint immár hagyományos szórakoztató-elektronikai eszköz elég jól vizsgázott. Viszont a megkérdezetteknek alig a fele (46,5\%) képes egyedül is $S M S$ - $t$ küldeni, és csupán negyedrészük $(23,2 \%)$ tud mobiltelefon-névjegykártyát egyedül küldeni vagy fogadni. Ugyancsak hasonló arányban (23,2\%) állítják azt, hogy egyedül is ki tudnak nyomtatni dokumentumokat a számítógépról - ez különösen azért nagyon alacsony arány, mert nem a nyomtató telepítésére vagy beállítására kérdeztünk rá, hanem egy már összeállított számítógép egyik fontos kimeneti perifériájának a használatára. A nyomtatási funkció szinte minden szoftverbe be van építve, és általában nagyon könnyen és logikusan használható. A számítógépen önállóan szöveget írni már többen tudnak: a megkérdezettek 31,9\%-a válaszolt igennel erre a kérdésre.

Az internetezéshez kapcsolódó tudást firtató kérdésekre kapott válaszok alapján azt láthatjuk, hogy az 50-75 éveseknek csupán egynegyed vagy még kisebb része tudja megbízhatóan és sokoldalúan használni az internetet. E-mail üzeneteket egyedül küldeni és fogadni, illetve azokat elolvasni a megkérdezettek 26,9\%-a képes, egy adott weboldalt az idôsebbek 25,4\%-a találna meg egyedül, de képeket vagy dokumentumokat már csak 18,4\%-uk tudna önállóan letölteni. Ez egyúttal azt is jelenti, hogy az adott korosztályban csupán minden ötödik idós embernek van egyáltalán esélye arra, hogy bonyolultabb múveleteket is végrehajtson, például igénybe vegye as e-kormány:ati szolgáltatásokat. Skype-on egy ismerósét a megkérdezettek 15,5\%-a tudná önállóan felhívni. Ez már valóban összetettebb kihívást jelent (több periféria is kell hozzá, kezelni kell az ismerốsök címjegyzékét, fel kell ismerni a hívott fél online jelenlétét stb.), de egy elốre beállított számítógépen ez sem lépi túl a felhasználói szintú ismereteket.

Bár az IKT eszközöket és szolgáltatásokat értékteremtố módon használók aránya a korosztályban meglehetôsen alacsony, érdemes felfigyelnünk arra, hogy itt most nem tudásbeli, hanem internet-hoz:áférési sæakadékról van šó. A megkérdezettek 29,6\%-ának van otthon internete, és ezeknek már a 90,8\%-a képes elektronikus úton önállóan le- 
velezni, továbbá 85,8\%-uk egyedül rátalál a keresett weboldalra. 62\%-uk képeket és dokumentumokat is tud önállóan letölteni, és az idôs internethasználók fele (52,3\%) Skype programmal önállóan fel tudja hívni ismerôseit.

Az idösebb koros:tálynak azok a tagjai, akik hasะnálják az internetet, túlnyomó többségükben sikeresen megtanulták a kezelését, és önállóan képesek élni elönyeivel.

\section{Közel a segítség?}

A felhasználó nem mindig szorul rá, hogy önállóan oldja meg a feladatokat - egy kis segítség elérhetôsége esetén jelentôsen bôvül azoknak a köre, akik hozzáférnek a megfelelő́ technikai eszközökhöz. Fentebb láthattuk, hogy a megkérdezettek 69,5\%-a önállóan is be tudja állítani a TV-csatornákat. Azoknak a fele, akik önállóan nem képesek erre, kis segítséggel már meg tudná oldani a feladatot, és csupán a többiek ítélik meg úgy, hogy semmiképpen sem járnának sikerrel. A szükséges segítség mértékére nem kérdeztünk rá, de semmiképpen sem arról van szó, hogy a feladatot teljes mértékben valaki más végezné el.

Az alábbi táblázatban összegeztük, hogy az idôsek IKT-használóinak köre menynyiben bôvül ki, ha segítséget vesznek igénybe:

\begin{tabular}{|l|c|c|c|}
\hline & $\begin{array}{c}\text { Önállóan el tudja } \\
\text { végezni }\end{array}$ & Segitséggel tudja elvégezni & $\begin{array}{c}\text { Semmiképpen sem tudja } \\
\text { elvégezni }\end{array}$ \\
\hline TV-csatornák beállítása & $69,5 \%$ & $17,1 \%$ & $13,2 \%$ \\
\hline Szövegírás számítógépen & $31,9 \%$ & $20,7 \%$ & $45,1 \%$ \\
\hline SMS-küldés & $46,5 \%$ & $17,4 \%$ & $35,0 \%$ \\
\hline $\begin{array}{l}\text { Mobil- névjegykártya foga- } \\
\text { dása }\end{array}$ & $23,2 \%$ & $27,6 \%$ & $46,8 \%$ \\
\hline E-mail olvasása & $26,9 \%$ & $21,8 \%$ & $49,2 \%$ \\
\hline Nyomtatás & $24,2 \%$ & $22,2 \%$ & $51,7 \%$ \\
\hline Weblap megtalálása & $25,4 \%$ & $20,1 \%$ & $52,3 \%$ \\
\hline $\begin{array}{l}\text { Képek, dokumentumok le- } \\
\text { töltése }\end{array}$ & $18,4 \%$ & $23,5 \%$ & $55,8 \%$ \\
\hline Skype használata & $15,5 \%$ & $23,7 \%$ & $58,4 \%$ \\
\hline
\end{tabular}

A fenti adatok újra megerôsítik a különféle társadalmi közvetítoók (hivatásos vagy önkéntes szakemberek, barátok és családtagok) fontos szerepét nemcsak a képzésben, hanem a biztonságérzet növelésében is. Társadalmi közvetitók segitségével a digitális eszközöket hašnálók köre átlagosan legalább ötödével növelhetóo.

Ha csak azokat vesszük figyelembe, akiknek van otthoni internet-elófizetésük, ebben a körben átlagosan 50\%-kal gyarapodnának a fontosabb fenti készségek. Ha a hozzáférési különbség nem állna fenn, akkor a társadalmi közvetítók szerepe még nagyobb lehetne, és nemcsak az ötödével, hanem a felével növelhetné meg a gyakorlott felhasználók számát.

A megkérdezettek 81,4\%-a természetes módon valamilyen családtagjától vagy rokonától kapott segítséget egy-egy technikai eszköz beállításához. Barátoktól, szomszédoktól már csak a megkérdezettek negyedrésze kért segítséget, valamilyen más szakemberhez pedig csupán 16,6\%-uk fordult. Ez áll a digitális irástudás családon beliili 
terjedésének a hátterében, és ezért kritikus fontosságú, hogy az a családtag, aki kívülról „behozza” a tudást, valóban hozzáértő legyen - vagy tudjon kérdezni.

\section{Az internet valódi értéke}

Nehéz meghatározni, hogy az internet milyen értéket képvisel azok számára, akik elérik, és önállóan is rendszeresen használják. Kérdőívünk alapján vizsgálni tudtuk, milyen mértékú a bizalom, illetve mennyire interaktív az internethasználat az idôsek körében.

A televízió továbbra is fontosabb információforrás, mint az internet, hiszen az internetet a teljes célcsoportnak csak a 13,9\%-a használja gyakran vagy nagyon gyakran információszerzésre. Ez azt jelenti, hogy még azok köziil is, akik önállóan képesek egy weblapot megtalálni, csak minden harmadik személy használja elsódleges információforrásként az internetet. A vizsgált korosztályban a sajtó háromszor annyi, a televízió pedig hatszor annyinak ember számára jelent elsốdleges információforrást, mint az internet. A televízió iránt még mindig sokkal nagyobb a bizalom, mint az internet iránt a felhasználók körében is.

A háztartásban megtalálható internetre kötött számítógép egyáltalán nem jelenti azt, hogy az ott élő idôsek jelentốs mértékben hozzá is jutnak a használatához. Ha több generáció viszonylatában vizsgáljuk az otthoni internet-hozzáférés arányait, sejtett, de lehangoló eredményt kapunk: a felmérésünket megeloozoó hét folyamán a háromgenerációs hástartásokon belül a gyerekek 14,4\%-a és a szülók 9,9\%-a, ám a nagyszülóknek csupán 1\%-a hašnálta minden nap az internetet.

Az e-kormányzati és e-egészségügyi szolgáltatások akkor találnak majd kedvezô fogadtatásra (és kifejlesztésük akkor térül meg), ha a használók többsége képes lesz és akarja is kezelni azokat (és ehhez természetesen szükséges az is, hogy az önálló használók száma szignifikánsan növekedjen). Az információszerzési szokások tekintetében azt figyelhetjük meg, hogy a hagyományos, már bevált, ismert módszerek lecserélésére az emberek sokkal kevésbé hajlamosak, mint a „kockázat nélküli” tájékozódásra. $A$ z

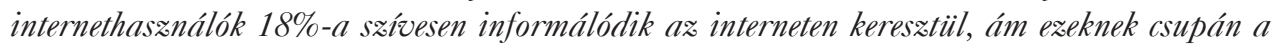
fele $(10 \%)$ élne a: online recept-felíratás lehetóségével.

Az internet-elófizetéssel rendelkezók 18\%-a „mindenképpen” informálódik online is az oót érintố egészségügyi kérdésekben, 28,6\% „talán”, több mint a felük (51,8\%) pedig egyáltalán nem teszi ezt meg. Csupán 10\%-uk venné igénybe mindenképpen a receptek interneten való felírásának lehetôségét, 19,19\%-uk talán igényelné ezt, közel 70\%-uk (68,68\%) azonban mereven elzárkózik ettól a lehetôségtól.

Az interaktív szolgáltatások igénybevételére való hajlandóság viszont egyértelmúen az önálló használat függvénye: az internetet önállóan és magabiztosan használni tudóknak a fele $(48,9 \%)$ „mindenképpen” vagy „talán” hajlamos az internet információforrásként való használatára e-egészségügyi kérdésekben, és közel egyharmad részük $(30,4 \%)$ így viszonyul az online receptfelíráshoz is.

Az idósek nyitottsága az életminôséget javító technológiai eszközök iránt

Az adatok elsôdleges elemzésén túl nyilvánvalóan az a legfontosabb kérdés, hogy milyen az idôsek hozzáállása az általuk már ismert és a számukra még ismeretlen technikai berendezések használatához. Kérdôívünkben rákérdeztünk, hogy igénybe ven- 
nének-e távfelügyelet, jelzốrendszeres házi segítségnyújtást, távdiagnózist, akadálymentesítést az otthonukban, felíratnának-e receptet az interneten, tájékozódnának-e online az egészségügyi kérdésekben, s végül használnák-e az intelligens otthonok nyújtotta szolgáltatásokat.

A kérdésre adott elsôdleges válaszokon túl általánosságban is tájékozódni akartunk az idôsek nyitottságáról. Mivel nem a lehetôségekre, hanem a kulturális háttérre voltunk kíváncsiak, merészen függetlenítettük a kérdést az anyagi változóktól, és loglineáris elemzés segítségével forgatókönyveket vázoltunk fel, amelyek azt rajzolták ki, hogy az egyes technikai megoldások iránti nyitottság vagy éppen elzárkózás milyen mintázatok mentén mozog.

A loglineáris elemzésbe hét változót vontunk be, így a válaszok mögött meghúzódó kulturális logika feltárását egy hétdimenziós mátrix segítette (backward elimination model). A modell illeszkedik, sốt, a szignifikancia eltérésének nagy mértéke éppenséggel túlilleszkedést mutat, ami szintén a kevés, de erôs kapcsolat megállapítását támasztja alá. Az alábbi táblázatban a négy legjellemzóbb (legnagyobb elemszámú) forgatókönyvet emeltük ki, amelyek átlépték a 10\%-os küszöböt:

\begin{tabular}{|c|c|c|c|c|c|c|c|}
\hline $\begin{array}{l}\text { Válaszadók } \\
\text { sæázalékos } \\
\text { aránya a } \\
\text { forgató-köny- } \\
\text { vekben }\end{array}$ & $\begin{array}{c}\text { Van-e } \\
\text { otthon } \\
\text { internet? } \\
(40)\end{array}$ & $\begin{array}{c}\text { Távfelïgye- } \\
\text { letet igénybe } \\
\text { venne-e? } \\
(38 a)\end{array}$ & $\begin{array}{l}\text { Távdiagnó- } \\
\text { zist igénybe } \\
\text { venne-e? } \\
(38 b)\end{array}$ & $\begin{array}{c}\text { Akadálymen- } \\
\text { tesitést az } \\
\text { otthonában } \\
\text { igénybe ven- } \\
\text { ne-e? (38c) }\end{array}$ & $\begin{array}{c}\text { Online } \\
\text { iratna-e fel } \\
\text { receptet? } \\
(38 d)\end{array}$ & $\begin{array}{c}\text { Online } \\
\text { tájékozódna-e } \\
\text { egészségügyi } \\
\text { információk- } \\
\text { ról? }(38 e)\end{array}$ & $\begin{array}{l}\text { Intelligens } \\
\text { otthon szol- } \\
\text { gáltatásokat } \\
\text { igénybe ven- } \\
\text { ne-e? ((38f) }\end{array}$ \\
\hline $20,5 \%$ & $\mathrm{i}$ & $\mathrm{t}$ & $\mathrm{t}$ & $\mathrm{t}$ & $\mathrm{t}$ & $\mathrm{t}$ & $\mathrm{t}$ \\
\hline $13,2 \%$ & $\mathrm{i}$ & $\mathrm{t}$ & $\mathrm{t}$ & $\mathrm{t}$ & $\mathrm{m}$ & $\mathrm{m}$ & $\mathrm{m}$ \\
\hline $11,1 \%$ & $\mathrm{i}$ & $\mathrm{m}$ & $\mathrm{t}$ & $\mathrm{m}$ & $\mathrm{t}$ & $\mathrm{t}$ & $\mathrm{t}$ \\
\hline $10,4 \%$ & $\mathrm{i}$ & $\mathrm{t}$ & $\mathrm{t}$ & $\mathrm{m}$ & $\mathrm{t}$ & $\mathrm{t}$ & $\mathrm{t}$ \\
\hline
\end{tabular}

Jelmagyarázat: „i” = igen, ,t” = talán, „,m” = mindenképpen.

A parciális asszociációk a következó változók esetén mutattak kimutatható összefüggéseket: 40-38b (14), 38a-38c (8), 38d-38e (14), 40-38f (15), 38b-38f (11), 38e-38f (9), 40 (2) és 38b (2). A kapcsolatok jellemzóen nagyon sokadrendúek (lásd a zárójelben megadott adatokat), így - bár szignifikánsak - látens összefüggéseknek minôsíthetók.

A loglineáris elemzés fontos eredménye, hogy akiknek az otthonában még nincs jelen az új technológia (jelen esetben az internet), azok,nem nyitottak a fenti új megoldásokra sem, s a róluk alkotott véleményük esetleges, véletlenszerú. $E \approx a$ z összefüggés $a \approx t$ mutatja, hogy idósek körében szükség van az új technológiai lehetôségek megismertetésére, és a már megismert technológiák áttöró, illetve késóbb egymást erôsitó nyitottság-növelö hatását emeli ki.

A parciális asszociációk alapján a fentiek közül a távdiagnózis lehetne a leginkább véleményformáló (killer) alkalmazás.

Azok, akik már rendelkeznek internet-hozzáféréssel az otthonukban, sokkal nyitottabbak, és a véleményük is koncentráltabb. A négy legjellemzóbb forgatókönyv mindegyike olyanokhoz kapcsolódik, akiknek van az otthonukban internet-kapcsolat. A bizonytalanság azonban jellemzően nagyon magas, a válaszok többsége „talán”, 28 közül csupán 6 esetben találkozunk a „mindenképpen” döntéssel.

A fenti elemzésben csak a „talán” és a „mindenképpen” választási lehetôségeket vettük figyelembe. Ha a loglineáris elemzést kiterjesztjük a „nem” válaszokra is (és 
ezzel 21 dimenzióssá változtatjuk az elemzendô mátrixot), újabb fontos felismeréshez jutunk: a legjobban kirajzolódó, és gyakorlatilag egyetlen domináns minta egy teljesen tagadó logikai vonal, amely ráadásul olyanokra jellemzó, akik rendelkeznek otthoni internethozzáféréssel. Ez a minta 30,5\%-os erôsségével, ami a második helyezettének $(5,6 \%)$ közel a hatszorosa, messze felülmúlja minden más modellét. Ez azt jelenti, hogy a magyarországi idősek között a technológia megitélésében aะ as irányvonal rajzolódik ki legjobban, hogy a fenti szolgáltatások közül egyet sem próbálnának ki, annak ellenére, hogy már ismerôs számukra az internet.

\section{Összefoglalás}

Magyarországon az idősebb korosztály hozzáállását az új információs és kommunikációs technológiákhoz jelenleg elsôsorban az idegenkedés jellemzi. Természetszerúleg azoknak van markáns véleményük az új lehetốségekról, akik bizonyos mértékig már megismerkedtek az internettel. A legvilágosabban kirajzolódó vélemény egyértelmúen tartózkodó és elzárkózó, és az érdeklődók túlnyomó többsége is még bizonytalan.

Felmérésünk eredményeinek elemzése alapján szembetûnô, hogy jelentôs tudásšakadékokat azonosíthatunk. Világosan látszik tehát, hogy az idôs korosztály értékteremtô internethasználata ugrásszerúen növelhetô lenne, ezáltal pedig a hazai e-kormányzati és e-egészségügyi szolgáltatások sikeressége és a rájuk fordított költségek megtérülése is növekedne.

A rendszeres felhasználók számának növelése mellett szól, hogy az idôsebb korosztálynak azok a tagjai, akik használják az internetet, túlnyomó többségükben sikeresen megtanulták a kezelését, és önállóan képesek élni elónyeivel - ez mindenképpen bátorító lehet a jövendố felhasználók számára, és frappánsan cáfolja a kételyeket.

Bár a várható társadalmi és gazdasági nyereséget hitelt érdemlően nem lehet számszerúsíteni, a reprezentatív adatok alapján prognosztizálható, hogy a társadalmi közvetítók segítsége legalább a felével megnövelné a „hozzáférók” között a tényleges felhasználók számát, ugyanis igen sokan már csak minimális bizonytalanságokkal küzdenek és egy lépésre állnak a sikeres használattól. Ezek mind kulturális értelemben, mind mentálisan igénylik a saját tudásszintjüknek megfelelő segítséget. A társadalmi közvetítók segítségével valóban csökkenthetố a digitális megosztottság, és potenciálisan leküzdhetố az idősebb generációk kimaradása az információs társadalomból.

Azelemzett trendek összegzése alapján úgy látjuk, hogyazidôsek reintegrálódásának kulcsterülete egyértelmúen a képzés és az ismeretterjesztés. 